https://doi.org/10.26593/jihi.v17i1.3507.97-120

\title{
Jalan Terjal Implementasi Reconciliation and Healing Foundation oleh Korea Selatan dalam Hubungan dengan Jepang
}

\author{
Maria Aurelia Primastuti Puspasari ${ }^{1}$, Hermini Susiatiningsih ${ }^{2}$ \\ ${ }^{1}$ Departemen Hubungan Internasional Universitas Diponegoro; mariaurelia1014@gmail.com \\ ${ }^{2}$ Departemen Hubungan Internasional Universitas Diponegoro; h32minis22@gmail.com
}

\begin{abstract}
ABSTRAK
Comfort Women Agreement sebagai upaya penyelesaian isu comfort women diantara Korea Selatan dan Jepang telah tercapai di tahun 2015. Sebagai tindak lanjut dalam perwujudan skema perjanjian tersebut, salah satu kebijakan yang harus diimplementasikan oleh pemerintah Korea Selatan yakni mendirikan sebuah yayasan untuk memberi dukungan kepada semua mantan comfort women dalam penyembuhan luka psikologis melalui kontribusi dana dari anggaran Pemerintah Jepang. Namun Comfort Women Agreement dan pendirian yayasan yang kemudian dinamai Reconciliation and Healing Foundation masih ditanggapi dengan respon negatif dari masyarakat dan korban comfort women di Korea Selatan. Hal ini menjadi jalan terjal seperti hambatan yang dihadapi dalam proses implementasi Reconciliation and Healing Foundation dan berujung pada pembubaran yayasan tersebut pada tahun 2018. Penelitian ini bermaksud menjelaskan bagaimana faktor mendasar dan utama pada isi kebijakan Comfort Women Agreement yang belum mencerminkan kepentingan para korban comfort women dan faktor lingkungan implementasi dari kebijakan tersebut dapat berpengaruh dalam proses implementasinya. Untuk menganalisis fenomena tersebut akan menggunakan teori implementasi kebijakan dari Merilee S. Grindle. Hasil dari penelitian menunjukkan faktor konten kebijakan dan lingkungan implementasi sebagai faktor yang menimbulkan terbentuknya jalan terjal dalam proses implementasi Reconciliation and Healing Foundation di Korea Selatan.
\end{abstract}

Kata Kunci: Comfort women Agreement, implementasi kebijakan, Reconciliation and Healing Foundation, Korea Selatan, Jepang

\section{ABSTRACT}

The Comfort Women Agreement as an effort to resolve the issue of comfort women between South Korea and Japan was achieved in 2015. As a follow-up to the realization of the agreement scheme, one of the policies that must be implemented by the South Korean government is establishing a foundation to support all former comfort. women in healing psychological wounds through the contribution of funds from the Japanese Government budget. However, the Comfort Women Agreement and the establishment of a foundation which was later called the Reconciliation and Healing Foundation were still met with negative responses from the public and victims of comfort women in South Korea. This has become a steep path like the obstacles faced in the process of implementing the Reconciliation and Healing Foundation and led to the dissolution of the foundation in 2018. This study intends to explain how the basic and main factors in the content of the Comfort Women Agreement policy do not reflect the interests of victims of comfort women and how the implementation environment of this policy affects the implementation process. To analyze this phenomenon will use the theory of policy implementation from Merilee $S$. Grindle. The results of the study show that the content of policy and context of implementation are the factors that lead to the formation of a steep road in the implementation process of the Reconciliation and Healing Foundation in South Korea.

Keywords: Comfort women Agreement, policy implementation, Reconciliation and Healing Foundation, South Korea, Japan. 
98 Maria Aurelia Primastuti Puspasari \& Hermini Susiatiningsih | Jalan Terjal Implementasi Reconciliation and Healing

Foundation oleh Korea Selatan dalam Hubungan dengan Jepang

\section{Pendahuluan}

Isu comfort women menjadi salah satu isu yang hingga kini masih hangat diperbincangkan dan tak jarang menjadi penyebab ketegangan hubungan Korea Selatan-Jepang. Istilah comfort women ("慰安婦" diucapkan ianfu dalam bahasa Jepang, wianbu dalam bahasa Korea dan Wèi'ān fù dalam bahasa Mandarin), secara harafiah berarti comforting, consoling woman dan merupakan eufemisme untuk merujuk pada wanita-wanita oleh Jepang yang selama Perang Dunia II dijadikan sebagai penyedia layanan seksual untuk militer Jepang ${ }^{1}$.

Pada Desember 2011 dalam KTT KoreaJepang, Presiden Lee Myung-bak meminta pemerintah Jepang untuk menyelesaikan masalah comfort women. Lalu, pada tahun 2012 secara informal Jepang mengusulkan solusi kemanusiaan, yang dikenal sebagai Proposal Sasae, tetapi hal ini ditolak oleh pemerintah Korea Selatan dengan alasan pengakuan tanggung jawab negara diperlukan dan pada akhir tahun 2012 dilakukan kembali negosiasi tetapi tidak menghasilkan apapun ${ }^{2}$. Pada Maret 2014 Shinzo Abe menyatakan tidak akan mencabut ataupun merubah Pernyataan Kono dan permintaan maaf yang telah dikeluarkan oleh pemerintah Jepang sebelumnya tentang isu comfort women ${ }^{3}$. Dua

\footnotetext{
${ }^{1}$ Soh C, Sarah. Japan's National/Asian Women's Fund for 'Comfort women'. Pacific Affairs, 76, 209-233. 2003.

${ }^{2}$ Task Force on the Review of the Korea-Japan Agreement on the Issue of "Comfort women" Victims. Ministry of Foreign Affairs Republic of Korea Press. 2017.

${ }^{3}$ Reuters. (2014, maret 14). Japan's Abe says won't alter 1993 apology on 'comfort women'. Retrieved from https://www.reuters.com/article/us-japan-korea/japansabe-says-wont-alter-1993-apology-on-comfort-womenidUSBREA2D04R20140314
}

belas putaran konsultasi tingkat-Direktur Jenderal secara bilateral juga dilakukan untuk membahas comfort women yang diadakan dari 16 April 2014.

Pada tahun 2015, Jepang dan Korea Selatan sepakat untuk menyelesaikan masalah comfort women dalam kesepakatan pertama mereka sejak 1965 melalui kesepakatan Comfort women Agreement yang final dan irreversible). Dalam mewujudkan Comfort Women Agreement, telah disepakati bahwa Korea Selatan memiliki tanggung jawab untuk mengelola kontribusi dana dari anggaran pemerintah Jepang dengan mendirikan sebuah yayasan, kemudian dinamai Reconciliation and Healing Foundation, yang memberi dukungan kepada semua mantan comfort women dalam penyembuhan luka psikologis mereka ${ }^{4}$. Namun, pencapaian Comfort Women Agreement dan pendirian yayasan ini masih ditanggapi dengan respon kurang baik dari masyarakat dan korban comfort women di Korea Selatan, ditunjukkan dengan berlangsungnya demo menyuarakan protes mereka dan berujung pada pembubaran yayasan tersebut ${ }^{5}$.

Melihat isu comfort women masih membayangi kedua negara dikarenakan kebijakan ini belum dapat memberikan manfaat ataupun dampak positif bagi para korban sehingga perubahan yang ingin dicapai melalui kebijakan ini belum dapat terwujud terhadap isu Comfort Women Agreement dan

\footnotetext{
${ }^{4}$ Ministry of Foreign Affairs of Japan. Announcement by Foreign Ministers of Japan and the Republic of Korea at the Joint Press Occasion. Retrieved from https://www.mofa.go.jp/a_o/na/kr/page4e_000364.html

${ }^{5}$ The Kyunghyang Shinmun. Dissolution of the Reconciliation and Healing Foundation According to the Wishes of the Comfort women Victims. Retrieved from http://english.khan.co.kr/khan _art_view.html?artid $=201811221709077 \&$ code $=710100 \#$ csidx9635909110de36ab27cd870b872717a (Diakses 26 Juli, 2019)
} 
Reconciliation and Healing Foundation yang diharapkan menjadi penyelesaian final dan irreversible, sedangkan usia para korban sudah tidak muda lagi menunjukkan urgensi diperlukannya langkah-langkah yang lebih baik dalam menyelesaikan isu tersebut. Dengan memahami proses implementasi kebijakan yang sebelumnya telah dilakukan, menjadi hal penting untuk merencanakan langkah-langkah seperti apa yang perlu dilakukan berikutnya.

Argumen peneliti adalah bahwa jalan terjal seperti hambatan atau tantangan yang dihadapi dalam proses implementasi Reconciliation and Healing Foundation oleh Korea Selatan diakibatkan karena faktor isi kebijakan berkaitan dengan Reconciliation and Healing Foundation masih belum matang dan belum tepat sasaran untuk diimplementasikan. Sedangkan dalam lingkungan implementasinya, Reconciliation and Healing Foundation tidak memiliki dukungan dari rezim pemerintah yang berkuasa dan tidak ada kepatuhan penuh serta respon yang positif dari korban serta masyarakat.

\section{Teori}

Sebagai pengantar untuk menjawab fenomena yang terjadi, perlu dipahami konsep kejahatan perang yang berguna untuk memahami apa yang terjadi dalam Isu comfort women. Kejahatan perang dikodifikasikan dalam pasal 8 Statuta Roma dari International Criminal Court (ICC). Sebagaimana disebutkan dalam pasal tersebut bahwa kejahatan perang mencakup kejahatan seperti pelanggaran berat terhadap Konvensi Jenewa 12 Agustus 1949 dan pelanggaran serius lainnya terhadap hukum dan kebiasaan yang berlaku dalam konflik bersenjata internasional, dalam kerangka hukum internasional yang ditetapkan, seperti melakukan pemerkosaan, perbudakan seksual, pelacuran paksa, kehamilan paksa, sterilisasi paksa, atau segala bentuk kekerasan seksual lainnya yang juga merupakan pelanggaran berat Konvensi Jenewa ${ }^{6}$. Melalui penjelasan tersebut, dapat dipahami bahwa Jepang telah melakukan kejahatan perang melalui tindakan menyediakan comfort women yang mana mereka adalah wanita-wanita yang dipaksa menjadi pemuas seksual tentara Jepang selama masa Perang Dunia II. Perkiraan jumlah comfort women, termasuk yang berasal dari Jepang, berkisar dari 50.000 hingga $200.000^{7}$.

Guna terwujudnya rekonsiliasi dan perdamaian di dunia, salah satu cara yang diambil oleh aktor Hubungan Internasional adalah dengan mencapai kesepakatan terkait dengan sebuah isu. Liberalisme dalam hubungan internasional umumnya memiliki pandangan yang positif mengenai sifat manusia dan yakin bahwa akal pemikiran manusia akan membawa pada perwujudan perdamaian tanpa adanya kekerasan. Perdamaian tersebut dapat tercapai dan semakin nyata ketika manusia memakai akal pikiran mereka untuk melakukan kerja sama yang saling menguntungkan dan bukanlah bersaing satu sama lain. Kerja sama ini bukan hanya dilakukan di dalam negara saja melainkan juga dalam lintas batas internasional $^{8}$.

Dengan kata lain, liberalisme lebih menekankan pentingnya kerja sama

\footnotetext{
${ }^{6}$ International Criminal Court. Rome Statute of the International Criminal Court, The Hague: International Criminal Court. 2011.

7 Soh C, Sarah. Japan's National/Asian Women's Fund for 'Comfort women'. Pacific Affairs vol 76, 209-233. 2003.

8 Jackson, Robert dan Georg Sorensen. Pengantar Studi Hubungan Internasional Teori dan Pendekatan Edisi Kelima (pp 175). Yogyakarta, Pustaka Pelajar Offset. 2005.
} 
dibandingkan dengan konflik dan perang. Liberalisme memiliki keyakinan terhadap akal dan juga prinsip-prinsip rasional yang ada dalam diri manusia. Liberalisme percaya apabila terdapat kesamaan kepentingan diantara aktor-aktor tersebut, maka mereka pun akan terlibat dalam aksi sosial yang kolaboratif dan kooperatif yang kemudian akan memicu terjalinnya kerja sama baik dalam lingkup domestik maupun internasional guna menyelesaikan berbagai bentuk masalah yang ada $^{9}$. Penggunaan teori liberalisme dalam tulisan ini menunjukkan bahwa agreement yang dilakukan oleh Jepang dan Korea Selatan dalam Comfort women Agreement bertujuan untuk mencapai kesepakatan dengan damai tanpa adanya konflik atau kekerasan yang terjadi diantara kedua negara.

Kesepakatan yang dicapai antara aktoraktor Hubungan Internasional perlu disesuaikan dengan kondisi di ranah domestik. Sebagaimana dijelaskan oleh James Anderson, dalam bukunya Public Policy Making bahwa "serangkaian kegiatan yang mempunyai maksud / tujuan tertentu yang diikuti dan dilaksanakan oleh seorang aktor atau sekelompok aktor yang berhubungan dengan suatu permasalahan atau suatu hal yang diperhatikan dalam lingkup masyarakat" merupakan sebuah kebijakan publik ${ }^{10}$.

Namun untuk menjawab rumusan masalah, penelitian ini menggunakan teori implementasi kebijakan menurut Merilee S. Grindle (1980) untuk menjelaskan faktor yang mempengaruhi dalam proses implementasi suatu kebijakan. Implementasi kebijakan menunjukkan aktivitas

${ }^{9}$ Jackson, Robert dan Georg Sorensen. Pengantar Studi Hubungan Internasional Teori dan Pendekatan Edisi Kelima (pp 175). Yogyakarta, Pustaka Pelajar Offset. 2005.

${ }^{10}$ Agustino, Leo. Dasar-Dasar Kebijakan Publik (pp 8). Bandung, Alfabeta. 2006 menjalankan kebijakan dalam ranah yang nyata. Kebijakan publik - pernyataan yang luas tentang tujuan, sasaran, dan sarana diterjemahkan ke dalam program aksi nyata untuk mencapai tujuan kebijakan ${ }^{11}$. Implementasi kebijakan adalah fungsi dari implementasi program dan bergantung pada hasilnya. Sehingga studi tentang proses implementasi kebijakan melibatkan penyelidikan dan analisis program tindakan konkret yang telah dirancang sebagai sarana untuk mencapai tujuan kebijakan yang lebih luas. Keberhasilan atau kegagalan proses implementasi dapat dievaluasi melalui apakah telah berhasil melaksanakan program sesuai dengan yang direncanakan dan tercapainya tujuan $^{12}$. Grindle (1980) membagi proses dari suatu implementasi kebijakan atau program aksi dipengaruhi oleh dua faktor yang utama yaitu, isi kebijakan (content of policy) dan lingkungan implementasi (context of implementation). Penelitian ini akan melihat faktor-faktor yang mempengaruhi terbentuknya jalan terjal dalam proses implementasi Reconciliation and Healing Foundation sebagai sebuah kebijakan lanjutan oleh pemerintah Korea Selatan dalam mewujudkan Comfort women Agreement.

\section{Analisis}

\section{A. Comfort women dan Comfort women Agreement}

Pada Agustus 1991, kesaksian publik pertama seorang korban, Kim Hak-sun, memicu debat publik tentang masalah comfort

\footnotetext{
${ }^{11}$ Grindle, Merilee S. Politics and Policy Implementation in the Third World. Princeton, Princeton University Press. 1980.

${ }^{12}$ Grindle, Merilee S. Politics and Policy Implementation in the Third World. Princeton, Princeton University Press. 1980.
} 
women tidak hanya di Korea dan Jepang, tetapi juga di komunitas internasional. Presiden Kim meminta pemerintah Jepang untuk melakukan penyelidikan pencarian fakta tentang masalah comfort women. Pemerintah Jepang mengeluarkan Kono Statement pada Agustus 1993, mengakui bahwa militer Jepang masa perang telah terlibat dalam pendirian dan pengelolaan comfort stations, dan bahwa perekrutan, pemindahan, dan aktivitas lainnya berhubungan dengan comfort women dilakukan diluar kehendak korban secara keseluruhan. Pemerintah Jepang kemudian membentuk Asian Women's Fund atau AWF pada Juli 1995 dan melakukan pembayaran moneter kepada para korban sebagai tindakan kemanusiaan, bersama dengan surat permintaan maaf dari Perdana Menteri Jepang 13.

\section{Posisi pemerintah Jepang adalah} bahwa masalah comfort women telah diselesaikan melalui Agreement between the Republic of Korea and Japan Concerning the Settlement of Problems in Regard to Property and Claims and Economic Cooperation (selanjutnya disebut sebagai Claims Settlement Agreement) di tahun 1965 dan tidak memiliki tanggung jawab hukum. Di sisi lain, posisi pemerintah Korea adalah bahwa masalah comfort women sebagai bentuk kejahatan belum diselesaikan oleh perjanjian tersebut. Ketika isu mengenai comfort women ini tidak kunjung terselesaikan di antara Korea Selatan dan Jepang. Mahkamah Konstitusi Korea pada bulan Agustus 2011 mengeluarkan putusan bahwa sikap pemerintah Korea Selatan yang cenderung lamban dalam melakukan upaya nyata untuk mendorong Jepang melakukan

\footnotetext{
${ }^{13}$ Task Force on the Review of the Korea-Japan Agreement on the Issue of "Comfort women" Victims. Ministry of Foreign Affairs Republic of Korea Press. 2017
}

pertanggungjawaban atas isu comfort women dan dalam upaya perlindungan hak-hak dasar korban comfort women merupakan pelanggaran terhadap konstitusi. Putusan ini kemudian memiliki pengaruh yang kuat karena memperjelas tugas pemerintah Korea Selatan untuk melakukan semua yang bisa dilakukan guna memperjuangkan korban comfort women mendapatkan permintaan maaf dan pertanggung jawaban dari pemerintah Jepang ${ }^{14}$. Setelah keputusan itu dikeluarkan, Kementerian Luar Negeri Korea Selatan secara resmi meminta pemerintah Jepang untuk memulai negosiasi atas masalah tersebut, sementara Jepang belum memberikan tanggapan konkret terhadap permintaan tersebut ${ }^{15}$.

Semenjak pelantikannya, Presiden Park Geun-hye secara terbuka semakin menjauhkan diri dari Jepang, dan mengatakan kepada BBC bahwa pertemuan antara negaranegara tetangga akan sia-sia tanpa adanya permintaan maaf resmi atas kekejaman yang dilakukan di bawah pemerintahan kolonial Jepang terkait isu comfort women ${ }^{16}$. Presiden Park terus menolak untuk mengadakan pertemuan bilateral dengan Jepang dengan alasan tersebut (Kumagai, 2016:66). Sehingga, terdapat seruan kuat dari publik untuk Presiden Park untuk mengadakan KTT bilateral,

\footnotetext{
${ }^{14}$ Yonhap News. (2011, Agustus 30). (LEAD) Court says Seoul's inaction over former 'comfort women' unconstitutional. Retrieved from https://en.yna.co.kr/view/AEN20110830007951315

${ }^{15}$ Asia-Japan Women's Resource Center. (2011). Comfort women": Korean constitutional court orders negotiation. Retrieved from http://www .ajwrc.org/eng $/$ modules/bulletin $/$ index.php? page $=$ article \&storyid=129

${ }^{16}$ The Diplomat. (2013, November 5). Park Geun-hye: Japan Summit 'Pointless' Without Apology. Retrieved from https://thediplomat.com/2013 /11/park-geun-hyejapan-summit-pointless-without-apology/
} 
ditunjukkan melalui survey bersama yang dilakukan oleh East Asia Institute (EAI) dan Genron NPO pada Mei 2013 dimana lebih dari $70 \%$ koresponden survey melihat perlunya diadakan KTT Jepang-Korea (Genron NPO, 2013). Dalam survei Juli 2014, jumlah persentase ini meningkat, dimana lebih dari $86 \%$ koresponden Korea Selatan dan 76\% koresponden Jepang melihat perlunya diselenggarakan KTT (EAI, 2014) ${ }^{17}$. Baik Korea Selatan-Jepang menganggap bahwa sengketa teritori Takeshima / Dokdo serta isu comfort women sebagai penghalang terbesar bagi pengembangan hubungan bilateral diantara keduanya ${ }^{18}$.

Semenjak tahun 1992, Korean Council for the Women Drafted for Military Sexual Slavery telah mengadakan Wednesday Demonstration, protes mingguan yang menuntut penyelesaian masalah comfort women dimana mereka meminta agar pemerintah Jepang memberikan pernyataan permintaan maaf dan memberikan kompensasi kepada para korban. Wednesday Demonstration telah menjadi wadah bagi masyarakat untuk mengingat, mengumpulkan solidaritas, dan mengedukasi mengenai isu ini. Wednesday Demonstration yang diselenggarakan oleh Korean Council for the Women Drafted for Military Sexual Slavery berkumpul untuk yang ke-1.108 sekaligus menandai peringatan ke-22 tahun dari berjalannya demonstrasi mingguan tersebut pada 8 Januari 2014. Anggota dewan termasuk

${ }^{17}$ East Asia Institute. (2014, Agustus 13). The 2nd Joint Korea-Japan Public Opinion Poll: Analysis Report on Comparative Data. Retrieved from http://www.eai.or.kr/main/english/program_view.asp?int Seq $=9367 \&$ code $=54 \&$ gubun $=$ program

${ }^{18}$ The Genron NPO. (2013, Mei 14). The 1st Japan-South Korea joint opinion poll. Retrieved from http://www.genron-npo.net/en/opinion polls/archives/5263.html korban comfort women dan 200 warga ambil bagian dalam demonstrasi tersebut ${ }^{19}$.

Dari demonstrasi yang telah dilakukan sejak 1992, diantara 237 korban hanya tinggal 56 yang masih hidup, mengingatkan bagaimana urgensi atas masalah comfort women ini untuk segera diselesaikan. Hal ini dipahami oleh Presiden Park yang menyatakan bahwa penyelesaian masalah ini sangat penting untuk dilakukan karena usia para korban yang selamat sudah sangat tua.

Menanggapi hal ini, Presiden Park Geun-hye semenjak pelantikannya di tahun 2013 mengambil langkah tegas terhadap Jepang dengan secara terbuka semakin menjauhkan diri dari Jepang, dan mengatakan bahwa pertemuan antara negara-negara tetangga akan sia-sia tanpa adanya permintaan maaf resmi atas kekejaman yang dilakukan di bawah pemerintahan kolonial Jepang terkait isu comfort women ${ }^{20}$. Presiden Park terus menolak untuk mengadakan pertemuan bilateral dengan Jepang dengan alasan tersebut $^{21}$.

Melihat ketegasan Korea Selatan atas isu comfort women, pada Maret 2014 Shinzo Abe akhirnya menyatakan tidak akan mencabut ataupun merubah Pernyataan Kono, yaitu permintaan maaf resmi yang telah dikeluarkan oleh Sekretaris Kabinet Jepang

19 The Kyunghyang Shinmun. (2016, Agustus 17). "'Selfelection' System of the 5 Board Director Members of the Reconciliation and Healing Foundation". Retrieved from http://news.khan.co.kr/kh_news/khan_art_view.html?art $\mathrm{id}=201608172156005$

${ }^{20}$ The Diplomat. (2013, November 5). Park Geun-hye: Japan Summit 'Pointless' Without Apology. Retrieved from https://thediplomat.com/2013/11/park-geun-hyejapan-summit-pointless-without-apology/

${ }^{21}$ Kumagai, Naoko. The Background to the JapanRepublic of Korea Agreement: Compromises Concerning the Understanding of the Comfort women Issue. Asia Pacific Review, 23, 1, 65-99. 2016. 
Yohei Kono pada tahun 1993 mengenai isu comfort women, karena mendapat protes dari Korea Selatan dan sejumlah pihak $^{22}$. Hal ini dapat dijelaskan dari bagaimana pemerintah Korea Selatan dan Jepang mendapatkan tekanan kuat dari sekutu mereka bersama, yaitu Amerika Serikat, yang menganggap bahwa masalah comfort women telah mencegah sekutu dekatnya untuk mempromosikan kerjasama bilateral. AS dengan sungguh-sungguh berkeinginan untuk mengkonsolidasikan segitiga keamanan ASKorea Selatan-Jepang guna secara efektif menanggapi Tiongkok dengan lebih tegas, terutama mengenai sengketa wilayah di Laut Cina Selatan dan perlunya menanggapi perubahan keseimbangan kekuatan Asia Timur Laut yang disebabkan oleh kebangkitan Tiongkok; untuk melawan krisis nuklir dan rudal Korea Utara; dan diskusi tentang General Security of Military Information Agreement (GSOMIA).

Kerja sama antara Jepang dan Korea Selatan dalam intelijen militer akan sangat penting di Semenanjung Korea. Untuk tujuan ini, pemerintah Amerika Serikat telah mendorong kedua negara menyetujui penyelesaian isu historis comfort women ${ }^{23}$. Comfort Women Agreement memungkinkan kerjasama keamanan trilateral yang lebih besar, membuka kembali kemungkinan

\footnotetext{
22 Reuters. (2014, maret 14). Japan's Abe says won't alter 1993 apology on 'comfort women'. Retrieved from.https://www.reuters.com/article/us-japankorea/japans-abe-says-wont-alter-1993-apology-oncomfort-women-idUSBREA2D04R20140314

${ }^{23} \mathrm{Ku}$, Yangmo. (2016, Februari 18). What is it for? Assessing the South Korea-Japan Deal on the Comfort women Issue. Retrieved from https://www.eir.info/2016/02/18/what-is-it-for-assessing-the-southkorea-japan-deal-on-the-comfort-women-issue/
}

penandatanganan GSOMIA dan Acquisition and Cross-Servicing Agreement (ACSA) yaitu persetujuan bilateral antara Amerika Serikat dan rekan koalisi maupun sekutu NATO-nya yang mengatur pertukaran sarana tempur seperti makanan, bahan bakar, pengangkutan, amunisi, dan perlengkapan antara kedua pihak. Serta, menyelesaikan secara politis masalah yang pernah mencegah kerjasama yang efektif antara Jepang dan Korea Selatan untuk terjalin dalam menghadapi berbagai ancaman keamanan ${ }^{24}$. Sehingga dalam kesempatan Nuclear Security Summit yang diadakan di Den Haag, Belanda pada 24-25 Maret 2014, Amerika Serikat kemudian berupaya meningkatkan hubungan KoreaJepang dari perspektif kerja sama Korea-ASJepang, dan KTT trilateral Korea-AS-Jepang yang terpisah diadakan pada tanggal 25 Maret 2014.

Pada prosesnya, Korea dan Jepang sepakat untuk meluncurkan konsultasi tingkat Direktur Jenderal untuk menangani masalah comfort women dari April 2014 hingga sehari sebelum pengumuman Comfort women Agreement. Comfort Women Agreement yaitu sebagai bentuk tanggung jawab penuh Jepang atas kesalahan pemerintahan Jepang dimasa lalu kepada wanita korban kejahatan Jepang yang telah diculik oleh pemerintah negara Jepang untuk pemenuhan kebutuhan biologis tentara Jepang yang dibentuk pada tanggal 28 Desember 2015. Hal yang telah disepakati dalam Comfort women Agreement yaitu Korea Selatan memiliki tanggung jawab untuk mengelola kontribusi dana dari anggaran pemerintah Jepang dengan mendirikan sebuah yayasan, yang dinamai dengan Reconciliation and Healing Foundation, yang memberi

\footnotetext{
${ }^{24}$ Lee, Kangkyu. The Comfort women Agreement: An Analysis Of The Motivations That Led To Park GeunHye's Acquiescence. Georgetown University, 17. 2017.
} 
dukungan kepada semua mantan comfort women dalam penyembuhan luka psikologis mereka $^{25}$.

Para Menteri Luar Negeri Korea dan Jepang bertemu di Seoul pada tanggal 28 Desember 2015 untuk mengkonfirmasi substansi Perjanjian, dan mengumumkan Perjanjian tersebut pada Konferensi Pers Bersama $^{26}$.

\section{B. Reconciliation and Healing Foundation dalam Skema Comfort women Agreement}

Pada pertemuan asosiasi kementerian terkait yang diadakan pada tanggal 30 Desember 2015, Kementerian Luar Negeri Korea Selatan mengusulkan draft "Rencana Pembentukan Yayasan" melalui Kementerian Kesetaraan Gender dan Keluarga. Pada tanggal 6 Januari 2016, Presiden Park menginstruksikan Kementerian Kesetaraan Gender dan Keluarga untuk melaksanakan pendirian yayasan tersebut ${ }^{27}$. Oleh karena itu, pada tanggal 29 Januari 2016, Kementerian Kesetaraan Gender dan Keluarga bersama dengan Kementerian Luar Negerimembentuk

${ }^{25}$ Reuters. (2014, maret 14). Japan's Abe says won't alter 1993 apology on 'comfort women'. Retrieved from.https://www.reuters.com/article/us-japankorea/japans-abe-says-wont-alter-1993-apology-oncomfort-women-idUSBREA2D04R20140314

26 Task Force on the Review of the Korea-Japan Agreement on the Issue of "Comfort women" Victims. Ministry of Foreign Affairs Republic of Korea Press. 2017.

${ }^{27}$ Ministry of Gender Equality and Family of Republic of Korea.( 2017, Desember 27). Ministry of Gender and Family Equality, [Reconciliation and Healing

Foundation] Reporting on Inspection Results and Others. Retrieved from http://www. mogef. go.kr /nw/enw/nw_enw_s001

d.do? $\mathrm{mid}=\mathrm{mda} 700 \& \mathrm{bbtSn}=705770$
"Public-Private Task Force (TF)" untuk pendirian yayasan serta melangsungkan prosedur yang diperlukan sebagai tujuan pendirian yayasan pada bulan Maret sampai April 2016. Setelah jajaran komite yayasan ini terbentuk pada Mei 2016, yayasan ini pun kemudian didirikan pada 28 Juli $2016{ }^{28}$. Reconciliation and Healing Foundation adalah non-profit organization yang telah memperoleh izin pendirian dari Kementerian Kesetaraan Gender dan Keluarga berdasarkan Pasal 32 UU Sipil Korea Selatan dan Pasal 4 Peraturan tentang Pembentukan dan Pengawasan Perusahaan Nirlaba di bawah Kementerian Kesetaraan Gender dan Keluarga $^{29}$.

Reconciliation and Healing Foundation memiliki visi untuk mengembalikan kehormatan dan martabat semua korban comfort women militer Jepang dan untuk menyembuhkan luka psikologis mereka. Dalam mewujudkan visi tersebut, perlu dirumuskan misi-misi yang menggambarkan strategi yayasan. Reconciliation and Healing Foundation memiliki beberapa misi sebagai berikut: (1) Langkah-langkah untuk mengembalikan kehormatan dan martabat semua korban comfort women; (2) Penyediaan layanan medis (termasuk penyediaan obat-obatan); Penyediaaan perawatan kesehatan, pemulihan dan nursing; dan (4) Tindakan lain yang sesuai yang mencerminkan tujuan Yayasan ${ }^{30}$.

\footnotetext{
${ }^{28}$ Ibid

${ }^{29}$ Reconciliation and Healing Foundation. n.d. Foundation Introduction. Retrieved from http://www.rhf.or.kr/main_sub/sub.php?folder $\mathrm{idx}=1 \&$ folder_page_idx $=1$

${ }^{30}$ Task Force on the Review of the Korea-Japan Agreement on the Issue of "Comfort women" Victims. Ministry of Foreign Affairs Republic of Korea Press. 2017.
} 
Program kerja yang akan dilaksanakan oleh yayasan ini guna mewujudkan visi dan misi mereka adalah dengan melalui: (1) Proyek individu, yaitu dengan pemberian dana kompensasi dari Jepang kepada para korban secara per-orangan; dan (2) Proyek untuk semua korban, yaitu kegiatan yang ditujukan dan melibatkan semua kelompok korban (Reconciliation and Healing Foundation, n.d).

Para korban comfort women yang berkenan menerima dana sebagai pelaksanaan proyek individu dari Reconciliation and Healing Foundation dapat mendaftarkan diri selama periode yang ditentukan, yaitu dari 10 Oktober 2016 hingga 30 Juni 2017. Reconciliation and Healing Foundation sendiri akan memberikan 20 juta won (US\$16,953 nilai tahun 2019) untuk korban yang telah meninggal dan 100 juta won (US\$84.766 nilai tahun 2019) untuk yang masih hidup dari dana yang diberikan Jepang. Untuk mengajukan permohonan dana ini, para korban comfort women atau representatif dari korban comfort women yang telah meninggal dapat mengunjungi yayasan atau dengan mengirimkan surat melalui pos. Untuk korban comfort women yang masih hidup dapat mengajukan permohonan saat dilakukan kunjungan individu ${ }^{31}$. Para korban comfort women yang masih hidup diwawancarai pada bulan Januari 2016 sampai bulan Juni 2017 sebanyak 1 hingga 7 kali secara individu oleh staf dari Kementerian Luar Negeri, Kementerian Kesetaraan Gender dan Keluarga serta pihak terkait dari yayasan ${ }^{32}$. Dari 34

\footnotetext{
${ }^{31}$ Reconciliation and Healing Foundation. n.d.

Foundation Introduction. Retrieved from http://www.rhf.or.kr/main_sub/sub.php

?folder_idx $=1 \&$ folder_page_idx $=1$

${ }^{32}$ Ministry of Gender Equality and Family of Republic of Korea.(2017, Desember 27). Ministry of Gender and Family Equality, [Reconciliation and Healing Foundation] Reporting on Inspection Results and Others.
}

korban comfort women yang mengisi formulir pemberian dana, sebanyak 7 orang menulis formulir mereka sendiri, 13 orang menulis secara langsung dan dibantu oleh orang lain karena mengalami hambatan, 10 orang dituliskan oleh orang lain, dan 4 orang formulirnya ditulis oleh wakil keluarga yang ditinggalkan ${ }^{33}$.

Dalam proses pelaksanaan implementasinya, Reconciliation and Healing Foundation tidak menghadapi jalan yang mulus. Hal ini ditunjukkan dengan protes dari publik, salah satunya protes yang dilakukan saat peresmian yayasan ini dan juga respon yang negatif dari beberapa korban comfort women yang sangat vocal ${ }^{34}$. Turbulensi politik dalam negeri Korea Selatan yang berujung pada pemakzulan Presiden Park Geun-hye pada Maret 2017, disusul dengan pemilu yang dimenangkan oleh Moon Jae-in pada Mei 20 $0^{35}$, berperan dalam kelangsungan implementasi Comfort women Agreement, termasuk dalam berjalannya Reconciliation and Healing Foundation. Pada pertengahan Juli 2017, kepala Reconciliation and Healing Foundation,

Retrieved from http://www.mogef. go.kr /nw/enw/nw_enw_s001d.do?mid=mda700\&bbtSn=70577 0

${ }^{33}$ Naver. (2017, Desember 27). Park Geun-hye orders to stop supporting UNESCO listing. Retrieved from https://m.news.naver.com/ read. .nhn mode $=$ LSD $\&$ mid $=$ sec $\&$ sid $1=100 \&$ oid $=469 \&$ ai $\mathrm{d}=0000264977$

${ }^{34}$ Korea Times. (2016, Agustus 2). Comfort women Foundation Spawns Dispute. Retrieved from https://www.koreatimes.co.kr/www/nation/2019/05/113 210974.html

\footnotetext{
${ }^{35}$ The Straits Times. (2017, Juli 25). Head of comfort women foundation by South Korean government to resign amid pressure. Retrieved from https://www.straitstimes.com/asia/east-asia/head-ofcomfort-women-foundation-by-south-koreangovernment-to-resign-amid-pressure
} 
Kim Tae-hyeon, kemudian menyatakan keinginannya untuk mengundurkan diri ${ }^{36}$. Lebih lanjut dalam pemerintahannya, Presiden Moon Jae-in membentuk satuan tugas di dalam Kementerian Luar Negeri untuk meninjau kembali Comfort Women Agreement ${ }^{37}$. Selain itu Kementerian Kesetaraan Gender dan Keluarga membentuk sebuah tim untuk melakukan investigasi dan audit terhadap Reconciliation and Healing ${ }^{38}$. Sehari sebelum Task Force menerbitkan laporan hasil peninjauan Comfort women Agreement di bulan Desember 2017, lima direktur komite Reconciliation and Healing Foundation dari delapan direktur yang tersisa mengajukan surat pengunduran diri ke kantor yayasan, membuat anggota dewan direksi yang tersisa berjumlah tiga orang ${ }^{39}$.

Fungsi yayasan ini kemudian menjadi terhenti di akhir tahun 2017 dikarenakan adanya rangkaian kejadian tersebut. Dengan hanya tiga direktur dari pemerintahan yang tersisa, Reconciliation and Healing Foundation tidak dapat berjalan dengan efektif,

36 The Straits Times. (2017, Desember 29). South Korean govt should rectify comfort women deal: The Korea Herald. Retrieved from

https://www.straitstimes.com/asia/east-asia/south-koreangovt-should-rectify-comfort-women-deal-the-koreaherald

${ }^{37}$ The Mainichi. (2017, Juli 25). Seoul to set up review panel over 'comfort women' accord with Japan. Retrieved from

https://mainichi.jp/english/articles/20170725/p2a/00m/0n $\mathrm{a} / 016000 \mathrm{c}$

${ }^{38}$ Korea Times.(2017, Juli 19). Moon unveils five-year policy roadmap. Retrieved from

http://www.koreatimes.co.kr/www/nation/2019/07/356_2 33272.html

${ }^{39}$ Hankyoreh. (2017, Desember 30). All the directors of the Reconciliation and Healing Foundation have resigned, virtually facing dissolution. Retrieved from http://www.hani.co.k r/arti /society/women/825657.html bahkan pada dasarnya tidak mungkin berfungsi sebagaimana yang seharusnya ${ }^{40}$. Korean Council for Justice and Remembrance mengkritik pemerintah karena tidak segera menutup Reconciliation and Healing Foundation. Seoul hanya mengatakan bahwa "musyawarah sedang berlangsung ${ }^{41}$. Korean Council for Justice and Remembrance memposisikan gerakan pemrotes di depan Kementerian Luar Negeri dan Reconciliation and Healing Foundation, yang terletak di lingkungan Jung di Seoul, untuk meminta pembubaran yayasan segera ${ }^{42}$. Ketika Moon bertemu dengan Abe pada 25 September 2018, di sela-sela Sidang Umum PBB, ia mengatakan bahwa Reconciliation and Healing Foundation gagal berfungsi sebagaimana mestinya, mengindikasikan pembubaran yayasan tersebut ${ }^{43}$. Pemerintah Korea Selatan kemudian mengambil langkah-langkah untuk mengganti dana Jepang dengan uang dari anggarannya sendiri $^{44}$. Melihat kenyataan ini dan rangkaian

${ }^{40}$ Yonhap News. (2011, Agustus 30). (LEAD) Court says Seoul's inaction over former 'comfort women' unconstitutional. Retrieved from https://en.yna.co.kr/view/AEN20110830007951315

${ }^{41}$ Hankyoreh. (2018, Juni 17). Court dismisses comfort women's suit against government for signing 2015 agreement with Japan. Retrieved from http://english.hani.co.kr/arti/english_edition/e_internation $\mathrm{al} / 849403 . \mathrm{html}$

${ }^{42}$ Ibid

${ }^{43}$ Lee, Kangkyu. The Comfort women Agreement: An Analysis Of The Motivations That Led To Park GeunHye's Acquiescence. Georgetown University. 2017.

\footnotetext{
${ }^{44}$ Kyodo News. (2018, Juli 24). S. Korea gov't approves fund to supplant Japan "comfort women" fund. Retrieved from https://english.kyodonews.net/
} 
protes yang dilakukan juga setelah berkonsultasi dengan korban, advokat mereka dan pihak-pihak terkait, pada 21 November 2018 Kementerian Kesetaraan Gender dan Keluarga mengumumkan pembubaran Yayasan $^{45}$.

Dari 47 korban comfort women yang masih hidup, sebanyak 36 orang yang bersedia meminta dana dari yayasan. Namun, pada akhirnya hanya 34 orang saja yang menerima dana tersebut, sedangkan 2 korban comfort women lainnya menyatakan penghentian dikarenakan keadaan kesehatan yang buruk dan kesulitan dalam menyatakan maksud. Selain itu, terdapat 2 korban comfort women yang berada dalam kondisi ketidakmungkinan untuk menerima dana tersebut karena sudah meninggal dan tidak ada keluarga yang tertinggal untuk diberikan dana tersebut ${ }^{46}$. Terdapat 9 orang yang menolak atas pemberian dana tersebut sedari awal dilakukannya konsultasi dengan korban, sedangkan 58 perwakilan keluarga dari 199 korban yang meninggal telah menerima dana tersebut $^{47}$. Hingga pembubarannya, yayasan

news/2018/07/c4c73447126e-s-korea-govt-approvesfund-to-supplant-japan-comfort-women-fund.html

45 The Kyunghyang Shinmun. (2018, November 22)

Dissolution of the Reconciliation and Healing Foundation According to the Wishes of the Comfort women Victims. Retrieved from http://english.khan.co .kr/khan_art_view.html? artid $=201811221709077 \&$ code $=710100 \#$ csidx 96359091 10de36ab27cd870b872717a

${ }^{46}$ Ministry of Gender Equality and Family of Republic of Korea.( 2017, Desember 27). Ministry of Gender and Family Equality, [Reconciliation and Healing Foundation] Reporting on Inspection Results and Others. Retrieved from http://www.mogef. go.kr/nw/enw/nw enw_s001d.do?mid $=$ mda700\&bbtSn $=705770$

${ }^{47}$ Kyodo News. (2018, Juli 24). S. Korea gov't approves fund to supplant Japan "comfort women" fund.https://english.kyodonews.net/news/2018/07/c4c734
Reconciliation and Healing Foundation masih belum dapat melakukan perencanaan ataupun perwujudan program kerja menyangkut proyek kegiatan yang ditujukan dan melibatkan semua korban comfort women sebagai realisasi kerja komprehensif yang mereka rencanakan diawal pendirian dalam rangka mencapai visi mereka untuk memulihkan kehormatan, martabat, dan menyembuhkan luka para korban.

\section{Faktor - Faktor yang Mempengaruhi Jalan Terjal yaitu hambatan atau tantangan dalam Implementasi Reconciliation and Healing Foundation}

Pada skema implementasi kebijakan Grindle ${ }^{48}$ sebuah kebijakan dapat diukur keberhasilan implementasinya melalui hasil kebijakan yang dicapai, yaitu bagaimana dampak, perubahan dan penerimaan pada masyarakat dan kelompok sasaran yang dihasilkan dari proses implementasi kebijakan tersebut. Telah dijelaskan bahwa implementasi Reconciliation and Healing Foundation sebagai bagian dalam perwujudan Comfort Women Agreement masih menemui jalan yang terjal yaitu hambatan atau tantangan seperti respon negatif dengan penolakan dari masyarakat, kelompok sasaran korban comfort women hingga pihak-pihak oposisi, hingga berujung pada pembubaran yayasan tersebut pada masa pemerintahan Moon Jae-in. Hasil kebijakan yang sedemikian rupa dapat dianalisis dengan melihat faktor-faktor yang mempengaruhi dalam proses implementasinya. Menurut Grindle, proses dari suatu

47126e-s-korea-govt-approves-fund-to-supplant-japancomfort-women-fund.html

${ }^{48}$ Grindle, Merilee S. Politics and Policy Implementation in the Third World (pp 11). Princeton, Princeton University Press. 1980 
implementasi kebijakan dipengaruhi oleh dua faktor yang utama yaitu, isi kebijakan (content of policy) dan lingkungan implementasi (context of implementation).

\section{Faktor Content of Policy}

Pada content of policy, Grindle dalam Subarsono ${ }^{49}$ menyampaikan bahwa terdapat beberapa variabel yang mempengaruhi implementasi kebijakan, yang pertama yaitu kepentingan kelompok sasaran dalam isi kebijakan. Termuatnya kepentingan kelompok sasaran dalam sebuah kebijakan akan berpengaruh memberikan dukungan yang positif terhadap implementasinya. Memulihkan kehormatan dan martabat korban serta menyembuhkan luka psikologis comfort women dalam kerangka kerja "pelaku versus korban" menjadi kunci utama, sehingga victimcentered approach haruslah hadir dalam penyelesaian masalah comfort women. Dalam rangka memberikan pemulihan bagi para korban, partisipasi mereka menjadi aspek yang terpenting, dan pemerintah memiliki tanggung jawab untuk mengumpulkan serta mencerminkan maksud dan posisi para korban ketika terlibat dalam negosiasi diplomatik. Namun demikian dalam kebijakan terkait Reconciliation and Healing Foundation dipandang hanya mencerminkan posisi dari pemerintah saja ${ }^{50}$.

Variabel yang kedua adalah jenis manfaat yang diterima oleh kelompok sasaran.

${ }^{49}$ Subarsono. (2005). Analisis Kebijakan Publik Konsep, Teori dan Aplikasi (pp 83). Yogyakarta : Pustaka Pelajar.

${ }^{50}$ Task Force on the Review of the Korea-Japan Agreement on the Issue of "Comfort women" Victims. Ministry of Foreign Affairs Republic of Korea Press. 2017.
Menurut Grindle dalam Agustino ${ }^{51}$, dalam suatu kebijakan harus terdapat beberapa jenis manfaat yang menunjukkan dampak positif yang dihasilkan oleh pengimplementasian kebijakan yang hendak dilaksanakan. Demikian kebijakan terkait Reconciliation and Healing Foundation diharapkan dapat memberikan manfaat yang tepat dan positif bagi kelompok sasaran, yaitu para korban comfort women. Melalui program kerja yayasan diharapkan dapat memberikan manfaat positif yaitu dimana para korban comfort women yang telah berusia lanjut mendapatkan kehormatan dan martabat korban comfort women kembali, serta untuk menyembuhkan luka psikologis mereka. Terutama dengan dana yang diberikan bagi para korban untuk perawatan dan pemenuhan hidup mereka sehingga mereka dapat hidup dengan sejahtera dan lebih baik ${ }^{52}$. Namun, banyak yang mengkritik bahwa bantuan dana tunai dari yayasan tidak benar-benar membantu para korban seperti yang diharapkan. Ahn Shin-kwon, direktur House of Sharing tempat sepuluh korban comfort women tinggal, menyatakan bahwa sering terjadi kasus dimana uang bantuan yang ditujukan untuk para korban segera diserahkan ke rekening keluarga $^{53}$. Staf House of Sharing mengatakan bahwa 90\% keluarga akan mengurus dana yang diberikan untuk para korban comfort

\footnotetext{
${ }^{51}$ Grindle in Agustino, Leo. Dasar-Dasar Kebijakan Publik. Bandung, Alfabeta. 2006.

${ }^{52}$ Task Force on the Review of the Korea-Japan Agreement on the Issue of "Comfort women" Victims. Ministry of Foreign Affairs Republic of Korea Press. 2017.

${ }^{53}$ Hankyoreh. (2016, Desember 27). Betrayed the comfort women grandmothers, Reconciliation and Healing Foundation is still criticized. Retrieved from http: //www.hani.co.kr/arti/ politics/ diplomacy/776385.html
} 
women. Tentunya bukan merupakan hal yang aneh karena sebagian besar korban juga ingin memberikan sebagian dana tersebut kepada keluarganya. Namun banyak dari keluarga korban yang hanya mengambil dana tersebut dan kemudian meninggalkan kewajiban mereka untuk mendukung para korban ${ }^{54}$. Keraguan inilah yang kemudian membuat para korban menolak program kerja proyek individu oleh yayasan dan menjadi salah satu faktor penghambat dalam pelaksanaan implementasi.

Variabel yang ketiga adalah sejauh mana perubahan yang diinginkan oleh sebuah kebijakan. Menurut Grindle dalam Subarsono ${ }^{55}$. Suatu kebijakan yang bertujuan untuk mengubah sikap dan perilaku kelompok sasaran akan relatif lebih sulit untuk diimplementasikan. Tujuan yang ingin dicapai dari kebijakan Reconciliation and Healing Foundation adalah harapan bahwa ketika luka para korban telah tersembuhkan dan isu comfort women telah terselesaikan, hubungan harmonis Korea Selatan dengan Jepang tanpa adanya isu historis yang mengganjal akan terwujud. Hal ini menuntut para korban comfort women untuk mengubah sikap mereka dari yang selama ini penuh dengan kemarahan yang kuat terhadap Jepang atas penderitaan mereka, menjadi mampu menerima permintaan maaf dan penyesalan dari Jepang melalui Reconciliation and Healing Foundation tersebut $^{56}$. Namun apa yang menjadi tuntutan

\footnotetext{
${ }^{54}$ DongA. ( 2016, Mei 16). I received the living cost support every month but...tears of comfort women grandmother 'empty bank account'. Retrieved from http://www.donga.com/news/article/all/20190516/955451 $46 / 1$

${ }^{55}$ Grindle in Subarsono. Analisis Kebijakan Publik Konsep, Teori dan Aplikasi (pp 93). Yogyakarta, Pustaka Pelajar

${ }^{56}$ BBC. (2019, Februari 3). Obituary: Kim Bok-dong, the South Korean 'comfort woman'. Retrieved from https://www.bbc.com/news/world-asia-47042684
}

utama mereka, yaitu permintaan maaf sungguh-sungguh dengan mengakui tanggung jawab hukum oleh Jepang belum tercapai dalam isi kebijakan, sehingga membuat luka, rasa frustasi, kesedihan dan kekhawatiran para korban comfort women belum tersembuhkan ${ }^{57}$. Dari kenyataan tersebut, variabel ini turut menjelaskan mengapa implementasi Reconciliation and Healing Foundation menemui jalan yang terjal dengan belum berhasilnya mewujudkan perubahan sikap dan perilaku korban comfort women menjadi positif terhadap Jepang dan untuk menerima yayasan tersebut, kemudian menjadikan isu ini akan terus diangkat dan masih menjadi isu yang membayangi dinamika hubungan Korea Selatan dengan Jepang.

Variabel keempat yang mempengaruhi implementasi kebijakan adalah apakah letak sebuah program sudah tepat, dimana program tersebut berada dalam ruang lingkup lembaga yang sesuai dengan isu yang ditangani ${ }^{58}$. Letak implementasi Reconciliation and Healing Foundation ini sudah tepat dalam ranah tanggung jawab lembaga yang sesuai, yaitu menjadi tanggung jawab Kementerian Luar Negeri Korea Selatan dikarenakan Reconciliation and Healing Foundation merupakan perwujudan dari Comfort Women Agreement dimana Jepang merupakan salah satu pihak terkait. Hal ini sesuai dengan tugas diplomatik utama Kementerian Luar Negeri, yaitu mengejar diplomasi kerja sama yang penuh percaya diri dengan negara-negara

\footnotetext{
${ }^{57}$ Hankyoreh. (2018, Juni 17). Court dismisses comfort women's suit against government for signing 2015 agreement with Japan. Retrieved from http://english.hani.co.kr/arti/english_edition/e_internation al/849403.html

${ }^{58}$ Subarsono. (2005). Analisis Kebijakan Publik Konsep, Teori dan Aplikasi (pp 93). Yogyakarta : Pustaka Pelajar.
} 
tetangga ${ }^{59}$. Kementerian Kesetaraan Gender dan Keluarga diserahi tanggung jawab oleh Pemerintah Korea Selatan untuk perwujudan kerja Reconciliation and Healing Foundation juga telah sesuai dengan objektif dari Kementerian ini yaitu: (1) perencanaan dan koordinasi kebijakan perempuan, ; (2) pencegahan kekerasan terhadap perempuan dan perlindungan korbannya. Selain itu memiliki kesesuaian dengan fungsi Kementerian Kesetaraan Gender dan Keluarga untuk mencegah kekerasan seksual dan melindungi korbannya ${ }^{60}$.

\section{Context of Implementation}

Grindle ${ }^{61}$ menyampaikan bahwa ketika letak implementasi menjadi lebih tersebar, baik secara geografis maupun organisasional, tugas untuk mengeksekusi kebijakan tertentu menjadi lebih sulit, mengingat semakin banyaknya pihak yang terlibat. Demikian halnya yang terjadi pada proses implementasi Reconciliation and Healing Foundation. Meskipun implementasinya telah tepat terletak pada lembaga Kementerian terkait seperti yang telah dijelaskan di atas, namun pada kenyataannya dalam proses penganggaran dana untuk biaya operasional yayasan harus melewati prosedur-

${ }^{59}$ Ministry of Foreign Affairs of Republic of Korea. (n.d). Key Diplomatic Tasks. Retrieved from

http://www.mofa.go.kr/eng/wpge/m_5727/contents.do

${ }^{60}$ Ministry of Gender Equality and Family of Republic of Korea.( 2017, Desember 27). Ministry of Gender and Family Equality, [Reconciliation and Healing

Foundation] Reporting on Inspection Results and Others. Retrieved from http://www.mogef. go.kr /nw/enw/nw_enw

s001d.do?mid $=$ mda $700 \& b b t S n=705770$

${ }^{61}$ Grindle, Merilee S. Politics and Policy Implementation in the Third World (pp 10). Princeton, Princeton

University Press. 1980. prosedur Majelis Nasional Korea Selatan ${ }^{62}$. Dengan adanya peran lembaga Majelis Nasional, implementasi Reconciliation and Healing Foundation pun melibatkan lebih banyak atau seperti yang dikatakan Grindle bahwa letak implementasi menjadi lebih tersebar yang dapat mengakibatkan munculnya kesulitan dalam proses implementasi.

Variabel kelima yaitu kebijakan telah menyebutkan implementornya dengan detail. Data submisi anggota komite yang diterima oleh Kementerian Kesetaraan Gender dan Keluarga berjumlah 11 orang. Dari orangorang Kementerian Luar Negeri Asia Timurlaut, Kementerian Kesetaraan Gender dan Keluarga, serta Kementerian Pusat, terdapat nama-nama yang terus diajukan. Setelah melalui proses tersebut, terbentuk komite Reconciliation and Healing Foundation yang terdiri dari kepala direktur Kim Tae-Hyeon yang merupakan guru besar Sungshin Women's University; Kim Gyo-Shik, kepala direktur Asia Trust \& Investment co., ltd; Kim Jae-Ryeon selaku perwakilan dari firma hukum Lawon Sesang; Shim Gyu-Seon, perwakilan dari surat kabar Dong-ah Ilbo; profesor Univeristas Kookmin, Lee WonDeok; perwakilan dari firma hukum Sanji, Lee Eun-Kyeong; Menteri Kesetaraan Gender dan Keluarga, Lee Jeong-Shim; lalu Jeong ByeongWon dari Kementerian Luar Negeri Asia Timurlaut; Jo Hee-Yong, manajer Korea National Diplomatic Academy Research Center, dan kepala direktur pusat penelitian Sejong, Jin Chang-Su ${ }^{63}$.

\footnotetext{
${ }^{62}$ Women News.(2016, November 17). National Assembly Research Service "There is a problem with the government's budget for the Reconciliation and Treatment Foundation. Retrieved from http://www.womennews.co.kr/news/articleView.html?idx no $=99688$

${ }^{63}$ The Kyunghyang Shinmun. (2016, Agustus 17). "'Selfelection' System of the 5 Board Director Members of the
} 
Grindle menyampaikan bahwa kapabilitas, dukungan yang lebih besar dari elit politik, kepemilikan akses terhadap sumber daya, hingga kemampuan untuk menghadapi tuntutan lebih dari kelompok sasaran yang dimiliki oleh implementor akan mempengaruhi keberhasilan jalannya implementasi ${ }^{64}$. Kapabilitas dari implementor Reconciliation and Healing Foundation dapat ditunjukkan melalui bagaimana nama-nama yang terpilih menjadi dewan direksi komite yayasan merupakan nama-nama yang terus diajukan sebagai kandidat. Mereka merupakan para ahli dalam bidang yang dibutuhkan dan memang sudah dipercaya untuk diserahi tanggung jawab melaksanakan implementasi Reconciliation and Healing Foundation, sampai muncul sebutan self-election dalam pemilihan tersebut ${ }^{65}$.

Implementor ini tidak mampu untuk menghadapi tuntutan lebih dari kelompok sasaran, yaitu korban comfort women, karena para korban merasa tidak ada implementor yang paham betul mengenai comfort women. Hal ini ditunjukkan melalui alasan dibalik pengunduran diri Kim Tae-hyeon. Dilansir dari berbagai sumber yang terkait dengan yayasan, keputusan pengunduran diri Kim ini didasari karena Kim merasakan tekanan yang luar biasa di tempat kerja, terutama karena terbebani oleh

Reconciliation and Healing Foundation" . Retrieved from http://news.khan.co.kr/kh_news/khan_art_view.html?art_ id $=201608172156005$

${ }^{64}$ Grindle, Merilee S. Politics and Policy Implementation in the Third World. Princeton, Princeton University

Press. 1980.

65 The Kyunghyang Shinmun. (2016, Agustus 17). "“Selfelection' System of the 5 Board Director Members of the Reconciliation and Healing Foundation". Retrieved from http://news.khan.co.kr/kh_news/khan_art_view.html?art_ id $=201608172156005$ opini publik di Korea Selatan ${ }^{66}$. Tindakan Pemerintah Korea Selatan dengan membentuk Task Force on the Review of the Korea-Japan Agreement on the Issue of "Comfort women" Victims memberikan tekanan pada lima direktur komite Reconciliation and Healing Foundation lainnya karena tindakan tersebut memberikan peluang bagi publik untuk semakin menentang eksistensi yayasan yang kemudian mendorong mereka mengundurkan diri ${ }^{67}$. Selain itu, dalam perkembangan aktivitas Reconciliation and Healing Foundation, implementor tidak memiliki akses yang cukup terhadap sumber daya yang menjamin operasional yayasan yang menghambat proses implementasinya.

Selanjutnya pembahasan yang terakhir dari content of policy adalah apakah sebuah program implementasi kebijakan telah didukung oleh sumber daya yang memadai. Mengingat untuk merealisasikan tujuan kebijakan, maka sumber daya yang diperlukan harus terpenuhi ${ }^{68}$. Muncul permasalahan mengenai sumber daya yang digunakan untuk kebutuhan operasional dari yayasan tersebut. Hingga upacara pembukaan pada 28 Juli 2016, komite yayasan belum mengumumkan siapa yang sebenarnya akan menanggung biaya operasional. Reconciliation and Healing Foundation juga membutuhkan uang untuk

${ }^{66}$ The Straits Times. (2017, Juli 25). Head of comfort women foundation by South Korean government to resign amid pressure. Retrieved from https://www. straitstimes.com/asia/east-asia/head-of-comfort-womenfoundation-by-south-korean-government-to-resign-amidpressure

${ }^{67}$ Hankyoreh. (2017, Desember 30). All the directors of the Reconciliation and Healing Foundation have resigned, virtually facing dissolution. Retrieved from http://www.hani.co. kr/arti/ society/women/825657.html

${ }^{68}$ Grindle, Merilee S. Politics and Policy Implementation in the Third World. Princeton, Princeton University Press. 1980 
mendapatkan persetujuan untuk yayasannya, dan kebutuhan ini dibiayai oleh sumbangan pribadi sebesar 1 juta won dari kepala yayasan, Kim Tae-hyeon ${ }^{69}$. Sehingga selaras dengan yang telah disampaikan Grindle bahwa ketidakjelasan dan perdebatan mengenai biaya operasional yayasan yang merupakan sumber daya bagi berjalannya Reconciliation and Healing Foundation menjadi salah satu bentuk jalan terjal dalam implementasi yayasan tersebut.

Kemudian perlu dipertimbangkan konteks atau lingkungan di mana tindakan implementasi dilakukan. Implementasi sebagai proses pengambilan keputusan yang berkelanjutan yang melibatkan berbagai aktor, dimana aktor-aktor diminta untuk membuat keputusan yang mempengaruhi jalannya implementasi.

\section{Faktor Context of Implementation}

Dalam context of implementation terdapat beberapa variabel, yang pertama yaitu seberapa besar kekuatan, kepentingan, dan strategi yang dimiliki oleh para aktor yang terlibat dalam implementasi kebijakan. Dalam hal ini, banyak aktor diminta untuk membuat pilihan tentang alokasi sumber daya dan banyak aktor lainnya yang berupaya mempengaruhi keputusan. Seringkali, tujuan para aktor akan berada dalam konflik langsung satu sama lain dan hasil dari konflik ini dan akibatnya, dari siapa yang mendapatkan apa, akan ditentukan oleh strategi dan posisi kekuasaan masing-masing aktor yang terlibat ${ }^{70}$.

\footnotetext{
${ }^{69}$ Korea Times. (2016, Agustus 2). Comfort women Foundation Spawns Dispute. Retrieved from https://www .koreatimes.co.kr/www/nation /2019/05/113 210974.html

${ }^{70}$ Grindle, Merilee S. Politics and Policy Implementation in the Third World. Princeton, Princeton University Press. 1980.
}

Pada tahun 2016, Kementerian Kesetaraan Gender dan Keluarga menganggarkan 150 juta won untuk biaya operasional Reconciliation and Healing Foundation seperti biaya pegawai dan sewa kantor ${ }^{71}$. Namun pada peninjauan anggaran untuk tahun 2017, Majelis Nasional Korea Selatan memutuskan untuk tidak memberikan anggaran-anggaran terkait untuk yayasan tersebut ${ }^{72}$. Hal ini dilakukan karena National Assembly Research Service menemukan bahwa adanya cacat prosedural dalam pemberian anggaran tersebut tanpa melalui komite peninjauan ${ }^{73}$. Lebih lanjut, banyak pihak juga berpendapat bahwa pembiayaan operasional yayasan yang didirikan sebagai bentuk kompensasi Jepang dengan menggunakan anggaran pemerintah Korea Selatan ini tidak tepat ${ }^{74}$. Dari penjelasan

\footnotetext{
${ }^{71}$ Women News.(2016, November 17). National Assembly Research Service "There is a problem with the government's budget for the Reconciliation and Treatment Foundation. Retrieved from http://www.womennews.co.kr/news/articleView.html?idx no $=99688$

72 The Kyunghyang Shinmun. (2017, Februari 27). 500 million won out of 10.7 billion won in settlement money for the comfort women victim, going into operation expenses for the Reconciliation and Healing Foundation. Retrieved from http://news.khan.co.kr/kh_news/khan_art_view.html?arti $\mathrm{d}=201702270600001 \&$ code $=940100$

${ }^{73}$ Women News.(2016, November 17). National Assembly Research Service "There is a problem with the government's budget for the Reconciliation and Treatment Foundation. Retrieved from http://www.womennews.co.kr/news/articleView.html?idx no $=99688$

${ }^{74}$ The Kyunghyang Shinmun. (2017, Februari 27). 500 million won out of 10.7 billion won in settlement money for the comfort women victim, going into operation expenses for the Reconciliation and Healing Foundation. Retrieved from http://news.khan.co.kr/kh_news /khan art view.html artid $=201702270600001 \&$ code $=940100$
} 
tersebut terlihat bahwa terdapat konflik antara aktor yang terlibat dalam implementasi Reconciliation and Healing Foundation mengenai alokasi sumber daya.

Majelis Nasional, merupakan lembaga legislatif nasional unikameral Korea Selatan, sebagai salah satu aktor memiliki kewenangan dalam mempertimbangkan dan memutuskan anggaran negara melalui proses yang bertujuan untuk mencerminkan pendapat publik dan untuk meningkatkan efisiensi dan kualitas operasi fiskal melalui pengawasan yang efektif Selain itu, hasil pemilihan parlemen pada bulan April 2016 di Korea Selatan menjadi kemungkinan penyebab hambatan lebih lanjut dalam implementasi Reconciliation and Healing Foundation. Selama pemilihan parlemen, partai Saenuri kehilangan mayoritas untuk pertama kalinya dalam 16 tahun. Ketua dan ketua kedua partai oposisi yang sekarang mengendalikan mayoritas di parlemen telah mengindikasikan bahwa mereka dengan gigih menentang Comfort women Agreement. Ketua baru dari Partai Minjoo, Choo Mi-ae, telah mendefinisikan Comfort women Agreement sebagai "bencana diplomatik yang belum pernah terjadi sebelumnya"75.

Dengan partai-partai oposisi sebagai mayoritas di parlemen, proses implementasi

Reconciliation and Healing Foundation sebagai bagian dari skema perwujudan Comfort Women Agreement pun menghadapi hambatan lebih lanjut. Ditunjukkan pada Februari 2017, Park Joo-min, anggota Majelis Nasional dari Partai Minjoo, mengusulkan resolusi mengenai pembubaran yayasan dan pengembalian uang kepada pemerintah

\footnotetext{
75 The Diplomat. (2016, September 6). South KoreaJapan Comfort women Agreement: Where Do We Go From Here? Retrieved from https://thediplomat.com/2016/09/south-korea-japancomfort-women-agreement-where-do-we-go-from-here/
}

Jepang ${ }^{76}$. Selaras dengan yang disampaikan oleh Komite Kesetaraan Gender dan Keluarga Majelis Nasional pada Februari, bahwa pemangkasan anggaran untuk yayasan bertujuan untuk membubarkan yayasan ${ }^{77}$. Majelis Nasional memiliki kekuatan dan legitimasi yang lebih besar dibandingkan dengan jajaran direksi Reconciliation and Healing Foundation dalam memutuskan alokasi sumber daya sehingga tindakan Majelis Nasional tersebut menjadi faktor yang mempengaruhi terhambatnya proses implementasi.

Variabel yang kedua menurut Grindle adalah karakteristik institusi dan rezim yang sedang berkuasa ${ }^{78}$. Proses implementasi Comfort women Agreement berjalan dalam dua rezim pemerintahan yang berbeda, yaitu rezim pemerintahan Park Geun-hye dan Moon Jae-in. Gaya manajemen pemerintahan Park Geun-hye yang ditandai oleh kerahasiaan dan kontrol topdown ini kemudian ditunjukkan dalam proses negosiasi Comfort Women Agreement dengan Jepang dan proses pendirian yayasan. Agar implementasi dapat berhasil dilaksanakan, suatu kebijakan tidak hanya harus jelas dan tidak ambigu, tetapi juga harus disetujui oleh pejabat politik dan administrasi di semua tingkatan dalam hierarki pemerintah, termasuk

\footnotetext{
${ }^{76}$ Yonhap News. (2017, Desember 29). Reconciliation and Healing Foundation Resignation of 5 Board members, only 3 workers left. Retrieved from https://www.yna.co.kr/view/ AKR20171229172500005

${ }^{77}$ The Kyunghyang Shinmun. (2017, Februari 27). 500 million won out of 10.7 billion won in settlement money for the comfort women victim, going into operation expenses for the Reconciliation and Healing Foundation. Retrieved from http://news.khan.co.kr/kh_news /khan_art_view.html?artid $=201702270600001 \&$ code $=94$ 0100

${ }^{78}$ Grindle, Merilee S. Politics and Policy Implementation in the Third World. Princeton, Princeton University Press. 1980
} 
oposisi $^{79}$. Sehingga rezim yang berkuasa harus dapat meyakinkan mereka yang tidak setuju agar menjadi setuju. Namun, di seluruh administrasi Park Geun-hye, kemacetan politik yang mana Park tidak pernah mencoba membujuk atau bernegosiasi dengan para pemimpin partai oposisi untuk mencapai kompromi di Majelis Nasional Korea Selatan merupakan masalah serius ${ }^{80}$.

Setelah proses pemakzulan Park berjalan, oposisi utama Korea Selatan, Partai Minjoo, secara terbuka mengungkapkan ketidaksetujuannya dengan berjanji untuk membatalkan perjanjian ini jika partai itu berhasil mendapatkan kekuatan presiden dalam pemilihan di tahun $2017^{81}$. Komitmen dan dukungan politis terhadap suatu kebijakan menjadi kewajiban bagi implementasi kebijakan yang sukses ${ }^{82}$. Namun, sedari awal Moon mencalonkan diri, ia dan partainya telah dengan sangat terbuka mengkritik pencapaian Comfort women Agreement. Hal ini menunjukkan adanya komitmen dan dukungan yang berkurang terhadap implementasi perjanjian tersebut dalam administrasi pemerintahannya.

Sikap administrasi pemerintahan Moon ini dapat dijelaskan melalui pemahaman akan

${ }^{79}$ Grindle, Merilee S. Politics and Policy Implementation in the Third World. Princeton, Princeton University Press. 1980

${ }^{80}$ Hahm, S. D., \& Heo, U. The First Female President in South Korea: Park Geun-hye's Leadership and South Korean Democracy. Journal of Asian and African Studies, 53 (5), 649-665. 2017

${ }^{81}$ Global Times. (2016, Desember 28). S. Korea main opposition party vows to annul Comfort Women Agreement with Japan. Retrieved from http:// www.globaltimes.cn/content/1026118.shtml

${ }^{82}$ Grindle, Merilee S. Politics and Policy Implementation in the Third World. Princeton, Princeton University Press. 1980. karakteristik pemerintahan Moon. Candlelight Revolution mewakili konsensus luas untuk memulai secara baru, pemerintah yang terbuka dan transparan. Mengingat sifat partisipatif budaya politik Korea Selatan, faktor publik tidak dapat diabaikan. Moon Jae-in secara terbuka menegaskan pentingnya kritis legitimasi demokrasi dan masukan publik dalam semua aspek pemerintahan, termasuk kebijakan luar negeri ${ }^{83}$. Dengan filosofi manajemen negara The People's Country, Just the Republic of Korea, kebijakan pemerintahannya dilaksanakan berdasarkan prinsip-prinsip yang mencerminkan pendapat warga negara dalam urusan negara, dan berfokus pada keadilan untuk rakyat. Moon meyakini bahwa kepentingan rakyat merupakan yang terutama dan membingkai kebijakannya melalui nilai 3P yaitu People, Prosperity dan Peace ${ }^{84}$. Dengan seruan dan protes yang tiada henti dari masyarakat Korea Selatan dan korban, pemerintahan Moon yang menitikberatkan pada masukan dari publik dan kepentingan rakyat kemudian mendorongnya untuk melakukan serangkain peninjauan terhadap Comfort Women Agreement dan implementasi Reconciliation and Healing Foundation yang berujung pada keputusan untuk membubarkan yayasan tersebut.

Variabel yang terakhir menurut Grindle yaitu kepatuhan dan responsivitas kelompok sasaran. Keberhasilan implementasi kebijakan dipengaruhi oleh kepatuhan yang baik serta respon yang positif dari kelompok sasaran. Semenjak tahun 2016, Ahn Shinkweon, direktur kediaman House of Sharing tempat tinggal sepuluh orang comfort women

\footnotetext{
${ }^{83}$ Delury, John. The Candlelight Mandate \& Moon Jaein's Inter-Korean Dilemma. Joint U.S.-Korea Academic Studies, . 50-68. 2018.

${ }^{84}$ Kwak, S. Korea's New Southern Policy: Vision and Challenges. KIEP Opinions, 1-6. 2018.
} 
yang masih hidup telah mengatakan kepada media Hankyoreh dalam sebuah wawancara telepon bahwa Reconciliation and Healing Foundation perlu menghentikan proyek distribusi dana dari Jepang itu dan bersikukuh menyampaikan keberatan mereka untuk menerima dana melalui protes dan pernyataan resmi di konferensi pers ${ }^{85}$. Tidak berhenti di situ, pada 31 Agustus 2016, pemerintah Jepang melakukan pembayaran 1 miliar yen kepada Reconciliation and Healing Foundation. Namun pada hari yang sama, Justice and Memory Foundation for Resolving the Issue of Sex Slaves for the Japanese Army, yang didirikan oleh mantan comfort women Kim Bok-dong dan oleh kelompok-kelompok advokasi seperti Korean Council for the Women Drafted for Military Sexual Slavery by Japan, mengadakan konferensi pers di mana mereka menyerukan pembubaran yayasan dan berjanji untuk terus berjuang untuk mengembalikan hak-hak dan reputasi mantan comfort women dan untuk mencegah kekerasan seksual masa perang terjadi lagi ${ }^{86}$.

Fakta menunjukkan bahwa Pemerintah Jepang mengalokasikan uang tersebut dari dana daruratnya dengan nama, "sumbangan untuk organisasi internasional." Dalam anggaran Jepang, "sumbangan" memiliki konotasi hukum yang berbeda dari kompensasi dan reparasi. Istilah ini biasanya berlaku untuk proyek-proyek kemanusiaan ${ }^{87}$. Lebih lanjut

\footnotetext{
${ }^{85}$ Hankyoreh. (2016, Desember 27). Betrayed the comfort women grandmothers, Reconciliation and Healing Foundation is still criticized. Retrieved from http://www.hani.co.kr/arti/politics /diplomacy/776385.html

${ }^{86}$ Hankyoreh. (2016, September 1). Comfort women survivors say cash payments of 100 million won "won't change history. Retrieved from http://english.hani.co.kr/arti/english_edition/e_national/7 59483.html

${ }^{87}$ Ibid.
}

pada bulan Oktober tahun yang sama, Perdana Menteri Shinzo Abe mengatakan kepada Lower House Committee bahwa pemerintah Jepang sama sekali tidak mempertimbangkan memberikan surat permintaan maaf yang sungguh-sungguh kepada mantan comfort women Korea Selatan ${ }^{88}$. Sifat dana yang demikian dan pernyataan Abe tersebut kemudian memicu kontroversi yang semakin membuat beberapa korban bersikeras untuk menolak menerima dana tersebut. Dua belas orang korban comfort women yang masih hidup juga mengajukan tuntutan terhadap pemerintah Korea Selatan pada Agustus 2016 untuk menuntut ganti rugi 1,2 miliar won, dengan mengklaim bahwa pemerintah telah melanggar hak individu korban untuk mengklaim ganti rugi dan tanggung jawab hukum lebih lanjut dari Jepang dengan menandatangani Comfort Women Agreement tanpa berkonsultasi dengan para korban sendiri ${ }^{89}$.

Semenjak pendiriannya, Reconciliation and Healing Foundation telah mendapatkan respon negatif dari publik, aktivis, dan juga korban. Peresmian yayasan ini di tahun 2016 silam disambut dengan protes dari sekelompok mahasiswa dan aktivis sosial dimana sekitar 20 mahasiswa juga bentrok dengan polisi, menunda jalannya konferensi pers ${ }^{90}$. Protes-

\footnotetext{
${ }^{88}$ The Straits Times. (2017, Desember 29). South Korean govt should rectify comfort women deal: The Korea Herald. Retrieved from https://www.straitstimes.com/asia/east-asia/south-koreangovt-should-rectify-comfort-women-deal-the-koreaherald

${ }^{89}$ Hankyoreh. (2018, Juni 17). Court dismisses comfort women's suit against government for signing 2015 agreement with Japan. Retrieved from http://english.hani.co.kr/arti/english_edition/e_internation al/849403.html

${ }^{90}$ Korea Times.( 2017, Juli 28). Foundation under probe over sex slave deal. Retrieved from
} 
protes menuntut pembubaran yayasan pun kerap dilakukan oleh para aktivis dan korban dengan alasan-alasan yang telah dijelaskan sebelumnya ${ }^{91}$. Dengan masih terdapatnya korban comfort women yang menolak untuk menerima dana kompensasi dari Jepang dengan menuntut pengembalian hak-hak dan reputasi mantan comfort women mengindikasikan bahwa bagi para mantan comfort women, kebijakan dan implementasi dari Reconciliation and Healing Foundation belum sepenuhnya tepat untuk memenuhi kebutuhan atas pengembalian kehormatan dan martabat serta penyembuhan luka psikologis mereka. Hal ini menjelaskan tingkat kepatuhan para korban comfort women yang tidak mencapai seratus persen, disertai dengan dukungan respon negatif yang sedemikian rupa dari masyarakat publik terhadap implementasi Reconciliation and Healing Foundation.

\section{Kesimpulan}

Sesuai dengan analisis menggunakan variabel-variabel dalam isi kebijakan dan lingkungan implementasi sebagai faktor yang mempengaruhi proses implementasi menurut Grindle, implementasi kebijakan terkait Reconciliation and Healing Foundation menghadapi jalan yang terjal yaitu hambatan atau tantangan karena isi kebijakan yang masih belum matang dan belum tepat sasaran mencerminkan kepentingan para korban comfort women untuk diimplementasikan. Sedangkan dalam lingkungan implementasinya, Reconciliation and Healing Foundation tidak

https://www.pressreader.com/korea-republic/the-koreatimes/20170728/281573765766214

${ }^{91}$ Hankyoreh. (2018, Juni 17). Court dismisses comfort women's suit against government for signing 2015 agreement with Japan. Retrieved from http://english.hani.co.kr/arti/english_edition/e_internation $\mathrm{al} / 849403 . \mathrm{html}$ memiliki dukungan dari rezim pemerintah yang berkuasa dan tidak ada kepatuhan serta respon yang positif dari korban dan masyarakat publik. Meskipun Korea Selatan dan Jepang telah berhasil menormalisasikan hubungan keduanya dan secara dekat bekerja sama, perbedaan paham akan Comfort Women Agreement diantara Korea Selatan dan Jepang sudah terlalu besar. Pembubaran Reconciliation and Healing Foundation yang dilakukan oleh Korea Selatan di tahun 2018 menjadi salah satu faktor memburuknya hubungan bilateral Korea Selatan dan Jepang dalam masa Pemerintahan Moon, salah satunya ditunjukkan dengan meningkatnya sengketa perdagangan antara keduanya di tahun 2019.

\section{Daftar Pustaka}

Buku:

A.G, Subarsono. (2005). Analisis Kebijakan Publik Konsep, Teori dan Aplikasi. Yogyakarta : Pustaka Pelajar.

Agustino, Leo. (2006). Dasar-Dasar Kebijakan Publik. Bandung: Alfabeta.

Grindle, Merilee S. (1980). Politics and Policy Implementation in the Third World. Princeton: Princeton University Press. Jackson, Robert dan Georg Sorensen. (2013). Pengantar Studi Hubungan Internasional Teori dan Pendekatan Edisi Kelima. Yogyakarta: Pustaka Pelajar Offset.

\section{Jurnal:}

Delury, John. (2018). The Candlelight Mandate \& Moon Jae-in's Inter-Korean Dilemma. Joint U.S.-Korea Academic Studies 2018, pp. 50-68. 
Fuazia, Rizka. (2017). Diplomasi Korea Selatan Mendesak Jepang Menandatangani Agreement On Comfort women Tahun 2011-2015. JOM FISIP Vol. 4 No. 1 - Februari 2017.

Hahm, S. D., \& Heo, U. (2017). The First Female President in South Korea: Park Geun-hye's Leadership and South Korean Democracy. Journal of Asian and African Studies, 53(5), pp. 649-665.

International Criminal Court. (2011). Rome Statute of the International Criminal Court. The Hague: International Criminal Court.

Kumagai, Naoko. (2016). The Background to the Japan-Republic of Korea Agreement: Compromises Concerning the Understanding of the Comfort women Issue. Asia Pacific Review, Vol. 23, No. 1, pp. 65-99.

Kwak, S. (2018). Korea's New Southern Policy: Vision and Challenges. KIEP Opinions, pp. 1-6.

Lee, Kangkyu. (2017). The Comfort women Agreement: An Analysis Of The Motivations That Led To Park GeunHye's Acquiescence. Georgetown University.

Soh, C. Sarah. (2003). Japan's National/Asian Women's Fund for 'Comfort women'. Pacific Affairs, vol. 76, no. 2, pp. 209-233.

Task Force on the Review of the Korea-Japan Agreement on the Issue of "Comfort women" Victims. (2017). Report on the Review of the Korea-Japan Agreement of December 28, 2015 on the Issue of "Comfort women" Victims. Ministry of Foreign Affairs Republic of Korea Press.

\section{Internet:}


100 million won "won't change history.

Tersedia di:

http://english.hani.co.kr/arti/english_edit ion/e_national/759483.html [Diakses pada 22 Agustus, 2019].

Hankyoreh. 2016, Desember 27. Betrayed the comfort women grandmothers, Reconciliation and Healing Foundation is still criticized. Tersedia di:

http://www.hani.co.kr/arti/politics/diplo macy/776385.html [Diakses pada 1 Agustus, 2019].

Hankyoreh. 2017, Desember 30. All the directors of the Reconciliation and Healing Foundation have resigned, virtually facing dissolution. Tersedia di: http://www.hani.co.kr/arti/society/wome n/825657.html [Diakses pada 18 Juli, 2019].

Hankyoreh. 2018, Juni 17. Court dismisses

comfort women's suit against government for signing 2015 agreement with Japan. Tersedia di:

http://english.hani.co.kr/arti/english_edit ion/e international/849403.html

[Diakses pada 21 Agustus, 2019].

Hankyoreh. 2018, September 4. Former comfort woman calls for disbandment of false "Reconciliation and Healing" Foundation. Tersedia di:

http://english.hani.co.kr/arti/english_edit ion/e international/860646.html [Diakses pada 21 Juli, 2019].

Korea Times. 2016, Agustus 2. Comfort women Foundation Spawns Dispute.

Tersedia di:

https://www.koreatimes.co.kr/www/nati on/2019/05/113_210974.html [Diakses pada 5 Juli, 2019].

Korea Times. 2017, Juli 19. Moon unveils fiveyear policy roadmap. Tersedia di: http://www.koreatimes.co.kr/www/natio n/2019/07/356_233272.html_[Diakses pada 22 Agustus, 2019].

Korea Times. 2017, Juli 28. Foundation under probe over sex slave deal. Tersedia di: https://www.pressreader.com/korearepublic/the-koreatimes/20170728/281573765766214 [Diakses pada 22 Agustus, 2019].

$\mathrm{Ku}$, Yangmo. 18 Februari 2016. What is it for? Assessing the South Korea-Japan Deal on the Comfort women Issue. Tersedia di: https://www.eir.info/2016/02/18/what-is-it-forassessing-the-south-korea-japan-dealon-the-comfort-women-issue/ [Diakses pada 1 Juni 2019].

Kyodo News. 2018, Juli 24. S. Korea gov't approves fund to supplant Japan "comfort women" fund. Tersedia di: https://english.kyodonews.net/news/201 8/07/c4c73447126e-s-korea-govtapproves-fund-to-supplant-japancomfort-women-fund.html [Diakses pada 25 Juli, 2019].

Ministry of Foreign Affairs of Japan. 2015. Announcement by Foreign Ministers of Japan and the Republic of Korea at the Joint Press Occasion. Tersedia di: https://www.mofa.go.jp/a o/na/kr/page4 e_000364.html [Diakses pada 10 September, 2019].

Ministry of Foreign Affairs of Republic of Korea. n.d. Key Diplomatic Tasks. Tersedia di: http://www.mofa.go.kr/eng/wpge/m_57 27/contents.do [Diakses pada 7 Agustus, 2019].

Ministry of Gender Equality and Family of Republic of Korea. 2017, Desember 27. Ministry of Gender and Family Equality, [Reconciliation and Healing 
Foundation] Reporting on Inspection

Results and Others. Tersedia di:

http://www.mogef.go.kr/nw/enw/nw_en

w_s001d.do?mid $=$ mda $700 \& b b t S n=7057$

70 [Diakses pada 28 Juni, 2019].

Ministry of Gender Equality and Family of

Republic of Korea. n.d. About the

Ministry. Tersedia di:

http://www.mogef.go.kr/eng/am/eng_am

f001.do [Diakses pada 10 Agustus, 2019].

Naver. 2017, Desember 27. Park Geun-hye orders to stop supporting UNESCO

listing. Tersedia di: https://m.news.naver.com/read.nhn?mod $\mathrm{e}=\mathrm{LSD} \& \mathrm{mid}=\mathrm{sec} \&$ sid $1=100 \&$ oid $=469$ \&aid $=0000264977$ [Diakses pada 1 Juli, 2019].

Reconciliation and Healing Foundation. n.d.

Foundation Introduction. Tersedia di:

http://www.rhf.or.kr/main_sub/sub.php?

folder_idx $=1 \&$ folder_page_idx $=1$

[Diakses pada 28 Juni, 2019].

Reconciliation and Healing Foundation. n.d.

Foundation Work. Tersedia di:

http://www.rhf.or.kr/main_sub/sub.php?

folder_idx $=4 \&$ folder_page_idx $=2$

[Diakses pada 28 Juni, 2019].

Reconciliation and Healing Foundation. n.d.

Project for Individual Victim. Tersedia

di:

http://www.rhf.or.kr/main_sub/sub.php?

folder_idx $=4 \&$ folder_page_idx $=2$

[Diakses 28 Juni, 2019].

Reuters. 2014, Maret 14. Japan's Abe says

won't alter 1993 apology on 'comfort

women'. Tersedia di:

https://www.reuters.com/article/us-

japan-korea/japans-abe-says-wont-alter1993-apology-on-comfort-womenidUSBREA2D04R20140314 [Diakses pada 5 Mei, 2019].
The Diplomat. 2013, November 5. Park Geunhye: Japan Summit 'Pointless' Without Apology. Tersedia di:

https://thediplomat.com/2013/11/parkgeun-hye-japan-summit-pointlesswithout-apology/ [Diakses pada 5 Mei, 2019].

The Diplomat. 2016, September 6. South

Korea-Japan Comfort women Agreement: Where Do We Go From

Here?. Tersedia di: https://thediplomat.com/2016/09/southkorea-japan-comfort-women-agreementwhere-do-we-go-from-here/ [Diakses pada 17 Agustus, 2019].

The Genron NPO. 2013, Mei 14. The 1st Japan-South Korea joint opinion poll. Tersedia di:

http://www.genron-

npo.net/en/opinion_polls/archives/5263.

html [Diakses pada 1 Mei, 2019].

The Genron NPO. 2015, Mei 28. The 3rd

Japan-South Korea Joint Public Opinion Poll (2015) Analysis Report on Comparative Data. Tersedia di: http://www.genronnpo.net/en/opinion_polls/archives/5263. html [Diakses pada 1 Mei, 2019].

The Kyunghyang Shinmun. 17 Agustus 2016. “'Self-election' System of the 5 Board Director Members of the Reconciliation and Healing Foundation" [online]. Dalam

http://news.khan.co.kr/kh_news/khan_ar t view.html?art id $=201608172156005$

[Diakses 12 Agustus, 2019].

The Kyunghyang Shinmun. 22 November 2018. "Dissolution of the Reconciliation and Healing Foundation According to the Wishes of the Comfort women Victims" [online]. Dalam http://english.khan.co.kr/khan_art_view. $\mathrm{html}$ ?artid $=201811221709077 \&$ code $=71$ 
0100\#csidx9635909110de36ab27cd870 b872717a [Diakses 26 Juli, 2019].

The Kyunghyang Shinmun. 2017, Februari 27. 500 million won out of 10.7 billion won in settlement money for the comfort women victim, going into operation expenses for the Reconciliation and Healing Foundation. Tersedia di: http://news.khan.co.kr/kh_news/khan_ar t_view.html?artid $=201702270600001 \& \mathrm{c}$ ode $=940100$ [Diakses pada 16 Agustus, 2019].

The Mainichi. 2017, Juli 25. Seoul to set up review panel over 'comfort women' accord with Japan. Tersedia di: https://mainichi.jp/english/articles/2017 0725/p2a/00m/0na/016000c [Diakses pada 15 Juli, 2019].

The Straits Times. 2017, Mei 10. Moon Jaein Claims Election Victory in South Korea. Tersedia di: https://www.straitstimes.com/asia/eastasia/moon-claims-election-victory-in-skorea [Diakses pada 15 Juli, 2019].

The Straits Times. 2017, Juli 25. Head of comfort women foundation by South Korean government to resign amid pressure. Tersedia di: https://www.straitstimes.com/asia/eastasia/head-of-comfort-womenfoundation-by-south-koreangovernment-to-resign-amid-pressure [Diakses pada 10 Juli, 2019].
The Straits Times. 2017, Desember 29. South Korean govt should rectify comfort women deal: The Korea Herald. Tersedia di: https://www.straitstimes.com/asia/eastasia/south-korean-govt-should-rectifycomfort-women-deal-the-korea-herald [Diakses pada 20 Agustus, 2019].

Women News. 2016, November 17. National Assembly Research Service "There is a problem with the government's budget for the Reconciliation and Treatment Foundation. Tersedia di: http://www.womennews.co.kr/news/arti cleView.html?idxno=99688 [Diakses pada 10 Agustus, 2019].

Yonhap News. 2011, Agustus 30. (LEAD) Court says Seoul's inaction over former 'comfort women' unconstitutional. Tersedia di: https://en.yna.co.kr/view/AEN20110830 007951315 [Diakses pada 1 Mei, 2019].

Yonhap News. 2017, Desember 29. Reconciliation and Healing Foundation Resignation of 5 Board members, only 3 workers left. Tersedia di: https://www.yna.co.kr/view/AKR20171 229172500005 [Diakses pada 20 Juli, 2019]. 